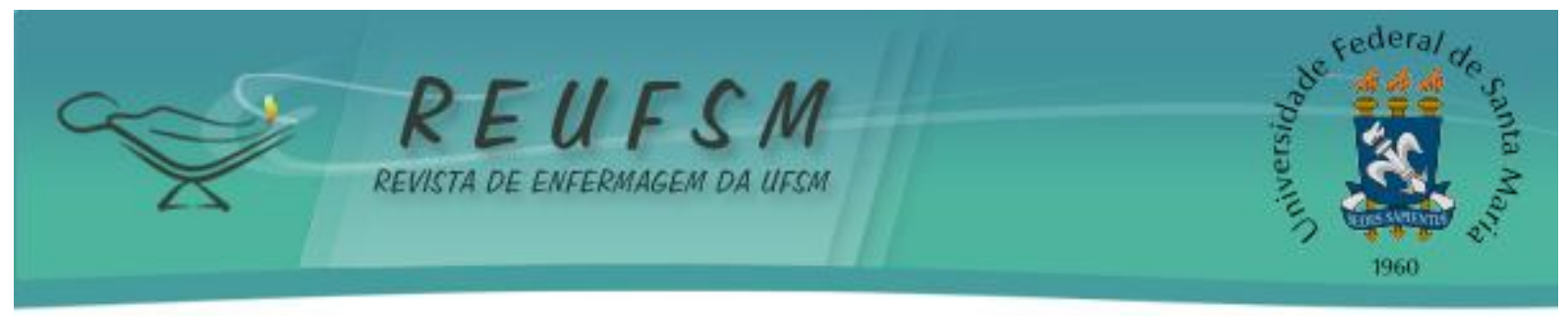

RESUMO

\title{
A DIMENSÃO GERENCIAL DO TRABALHO DO ENFERMEIRO EM UM SERVIÇO HOSPITALAR DE EMERGÊNCIA ${ }^{1}$
}

\author{
THE MANAGERIAL DIMENSION OF THE NURSE WORK IN A HOSPITAL EMERGENCY \\ SERVICE
}

\author{
LA DIMENSIÓN GERENCIAL DEL DE TRABAJO DEL ENFERMERO EN UN SERVICIO \\ HOSPITALARIO DE EMERGENCIA
}

\author{
José Luís Guedes dos Santos ${ }^{2}$ \\ Maria Alice Dias da Silva Lima ${ }^{3}$
}

RESUMO: Estudo com objetivo de analisar a dimensão gerencial do processo de trabalho do enfermeiro em um serviço hospitalar de emergência. Pesquisa qualitativa do tipo estudo de caso aprovada pelo Comitê de Ética da instituição de referência (09-151). Os dados foram coletados entre junho e setembro de 2009, mediante observação participante e entrevistas com 22 enfermeiros do Serviço de Emergência de um Hospital Universitário do Rio Grande do Sul - RS, e analisados a partir da técnica de análise de conteúdo temática. 0 trabalho dos enfermeiros é constantemente influenciado por situações inesperadas e pela procura por atendimento, que variam em diversidade e complexidade. A dimensão gerencial do trabalho do enfermeiro contempla a realização e o planejamento do cuidado, a previsão e provisão de recursos para o bom funcionamento da unidade e a liderança, supervisão e capacitação da equipe de enfermagem. Os enfermeiros reconhecem a importância do trabalho em equipe e sua responsabilidade na articulação das ações dos profissionais de saúde. A superlotação e manutenção da qualidade do cuidado são os principais desafios gerenciais dos enfermeiros. As estratégias para superá-los incluem mudanças no fluxo de atendimento dos pacientes e na estrutura física da unidade e a reorganização do sistema de saúde para a atenção às urgências. Esses resultados podem colaborar com o trabalho dos enfermeiros possibilitando que reflitam sobre suas práticas e avancem na compreensão da gerência do cuidado como instrumento para a melhoria das práticas de atenção à saúde nos serviços de emergência.

DESCRITORES: Enfermagem em emergência; Gerência; Papel do profissional de enfermagem.

ABSTRACT: This study aimed to analyze the managerial dimension of the nurse work in a hospital emergency service. Qualitative research approached as a case study approved by the Ethics Committee of the institution of reference (09-151). The data were collected between June and September 2009 through participant observation and interviews with nurses of the Emergency Service of a University Hospital of Rio Grande do Sul - RS, Brazil, and analyzed according to theme content analysis. The work of nurses is constantly influenced by unexpected situations and the great search of people to be attended to;

\footnotetext{
${ }^{1}$ Dissertação apresentada à Escola de Enfermagem da Universidade Federal do Rio Grande do Sul- EENF/UFRGS, Programa de Pós-Graduação em Enfermagem. Defesa: 26/04/2010.

2 Enfermeiro. Doutorando em Enfermagem pelo Programa de Pós-Graduação em Enfermagem da Universidade Federal de Santa Catarina (PEN/UFSC), Bolsista da Coordenação de Aperfeiçoamento de Pessoal de Nível Superior (CAPES). E-mail: joseenfermagem@yahoo.com.br.

3 Enfermeira. Doutora em Enfermagem, Professora Associada da EENF/UFRGS, Bolsista de Produtividade em Pesquisa do Conselho Nacional de Desenvolvimento Científico e Tecnológico (CNPq). E-mail: malice@enf.ufrgs.br.
} 


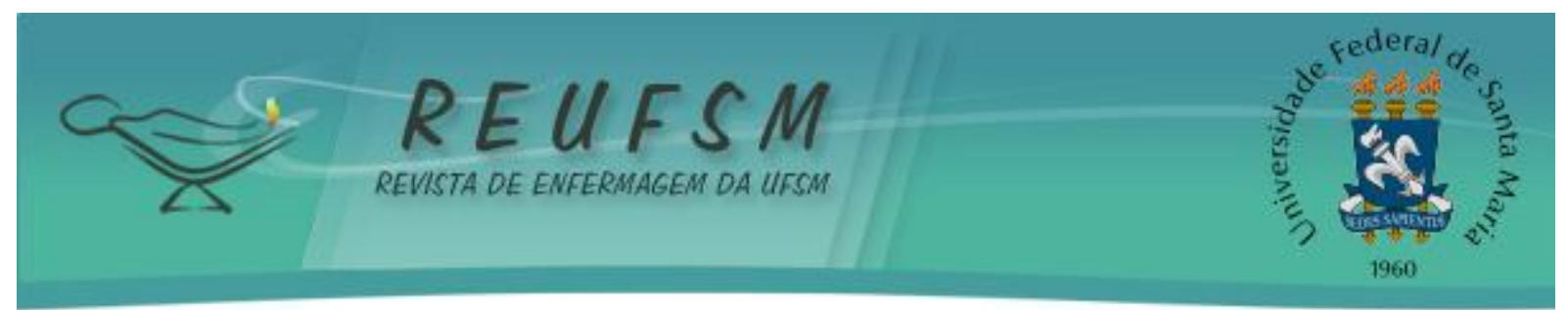

which varies in diversity and complexity. The managerial dimension of nurse's work focuses in the fulfillment of patients' needs and contemplates the accomplishment and care planning, prevision, provision of resources for the unit; as well as the leadership, supervision, and training of nursing team. Nurses recognize the importance of team work and their responsibility in joining health professional actions. Overcrowding and quality of care are the main challenges nurses face in managing care. The strategies to overcome them include changes in the flow of patients and physical structure of the unit and reorganization of the health system for emergency attention. These results might collaborate with the work of nurses enabling those professionals to reflect on their practices and advance in the comprehension of care management as a tool for assistance improvement and of the practices in health attention in emergency services.

DESCRIPTORS: Emergency nursing; Management; Nurse's role.

RESUMEN: Estudio con el objetivo de analizar la dimensión gerencial del proceso de trabajo del enfermero en un servicio hospitalario de emergencia. Investigación cualitativa de tipo estudio de caso aprobada por el Comité de Ética de la institución de referencia (09-151). Los datos fueron recogidos entre junio y septiembre de 2009, por medio de observación participante y entrevistas con enfermeros del Servicio de Emergencia de un Hospital Universitario del Rio Grande do Sul - RS, y analizadas según la técnica del análisis temático de contenido. El trabajo de los enfermeros recibe frecuentemente la influencia de situaciones inesperadas y de la gran búsqueda por atención, que varían en diversidad y complejidad. La dimensión gerencial del trabajo del enfermero comprende la realización y planificación del cuidado, la previsión y disposición de recursos para el buen funcionamiento de la unidad y el liderazgo, supervisión y capacitación del equipo de enfermería. Los enfermeros reconocen la importancia del trabajo en equipo y su responsabilidad en la articulación de las acciones de los profesionales de salud. La superpoblación de la unidad y la manutención de la calidad del cuidado son los principales retos de los enfermeros en su gerencia. Las estrategias para transponerlos incluyen cambios en el flujo de atención a los pacientes y en la estructura física de la unidad y la reorganización del sistema de salud para la atención a las urgencias. Esos resultados pueden colaborar con el trabajo de los enfermeros permitiendo que reflexionen sus prácticas, avanzando en la comprensión de la gerencia del cuidado como una herramienta para la mejora de las prácticas de atención a la salud en los servicios de emergencia.

DESCRIPTORES: Enfermería de urgencia; Gerencia; Rol del profesional de enfermería.

Data de recebimento: $11 / 01 / 2011$

Data de aceite:17/01/2011

Contato com autor responsável: José Luís Guedes dos Santos

E-mail: joseenfermagem@yahoo.com.br. 